\title{
Effects of severe energy and protein deficiencies on the fibres and nuclei in skeletal muscle of pigs
}

\author{
By N. C. STICKLAND* \\ Zoology Department, University of Hull, Hull \\ AND ELSIE M. WIDDOWSON \\ Department of Investigative Medicine, University of Cambridge, \\ Cambridge $C B_{2}$ I $Q N$ \\ AND G. GOLDSPINK \\ Zoology Department, University of Hull, Hull
}

\begin{abstract}
I. Measurements have been made of the size and number of muscle fibres and number of nuclei in a small indicator muscle ( $m$. flexor digiti $\mathrm{V}$ brevis) in the fore-foot of the pig. Wellnourished, ro-d-old and $\mathrm{I}$-year-old animals were studied, as well as $\mathrm{I}$ - and 2-year-old animals that were severely energy-deficient and protein-deficient.

2. The normal $\mathrm{I}$-year-old animals had much larger muscle fibres, with more nuclei, than the pigs in any of the other groups.

3. There were no significant differences between the numbers of fibres in the muscles of pigs in any of the four groups.

4. There was a significant difference between the number of fibres in the muscles of pigs coming from different litters, irrespective of their dietary history after birth. This suggests that the number of fibres is determined genetically before birth, and all that can take place after birth is an alteration in size.
\end{abstract}

Research on the skeletal muscle of laboratory animals has shown that different nutritional states can affect the size of a muscle by altering the size of the fibres within it (Goldspink, 1964), although the total number of fibres does not change. In farm animals, McMeekan (1940, I94I) found that feeding had a considerable effect on the diameter of muscle fibres in pigs, and Joubert (1956) reported that starvation decreased the diameter of the muscle fibres in sheep. Staun ( 1963 ) studied the effects of various levels of dietary protein on the skeletal muscle of pigs and found changes in the diameter of muscle fibres. Johnson (1971), working with bovine muscle, also found that fibre size was reduced by restricted nutrition. However, little accurate work has been done on the effect of nutrition on the total number of fibres in the muscles of farm animals. In a previous paper (Stickland \& Goldspink, I973) a small indicator muscle was described ( $\mathrm{m}$. flexor digiti $\mathrm{V}$ brevis) which behaved as did other muscles in the same pig. In particular the number and size of fibres in this muscle changed in parallel with those in the longissimus dorsi muscle. This small muscle can be removed entire and total muscle fibre counts can be made. It was decided, therefore, to use this indicator muscle in a study of skeletal muscle from pigs given low-energy and low-protein diets. The dietary deprivation in these experiments was much more

* Present address: Department of Veterinary Anatomy, University of Nairobi, PO Box 30197, Nairobi, Kenya. 
severe than that used in previous studies. Measurements were made of the number and size of the fibres, together with the number of nuclei in the muscles, and their DNA content.

\section{MATERIALS AND METHODS}

Animals and diets. Muscle samples were taken from Large White pigs from five litters which were being used in studies of the effects of severe energy and protein deficiencies. Thirteen piglets were fed on severely restricted amounts of the stock diet, containing $\mathrm{I} 80 \mathrm{~g}$ protein $/ \mathrm{kg}$, from Io $\mathrm{d}$ of age so that at the end of $\mathrm{I}$ year their bodyweights were only about $3 \%$ of normal (McCance, 1960). Six piglets were killed at that time and the remaining seven piglets were maintained on the same diet for a second year; they were allowed to grow from $6 \mathrm{~kg}$ at I year of age to 9-I I kg at 2 years of age. Ten ro-d-old piglets were given the same amount of the stock diet together with as much sugar or fat as they would eat (McCance, 1968). As they became older and more accustomed to the diet they ate more sugar or fat, so that by Io weeks of age they were eating enough to reduce the protein content of their diet from the normal r 80 to about $60 \mathrm{~g} / \mathrm{kg}$. These animals gained more weight than the energy-deficient ones and at the end of $\mathrm{I}$ year weighed $13-\mathrm{r} 9 \mathrm{~kg}$, some $7-8 \%$ of their 'expected' weight at that age. Five piglets were killed at this stage and the other five were maintained on the diet for a second year, by which time they weighed $16-29 \mathrm{~kg}$.

Five normal piglets aged ro d were killed and their muscles examined. This represented the situation at the start of the period of deprivation. Five pigs, reared normally, were killed at weights of about $200 \mathrm{~kg}$, at I year of age.

The ro-d-old pigs and the energy- and protein-deficient ones were killed by injection of a lethal dose of Nembutal (Abbott Laboratories Ltd, Queenborough, Kent) directly into the heart. The older control pigs were slaughtered in the usual manner at the abattoir. The required muscles were removed and examined as soon after death as possible.

Histological examination. The indicator muscle, $\mathrm{m}$. flexor digiti $\mathrm{V}$ brevis, from the left fore-foot was cleaned (but tendons were not cut) and fixed in situ for up to $30 \mathrm{~min}$ using glutaraldehyde solution $(25 \mathrm{~g} / \mathrm{l})$ adjusted to $\mathrm{pH}_{7 \cdot 2}$ with phosphate buffer (4I.5 ml $\mathrm{NaH}_{2} \mathrm{PO}_{4} \cdot \mathrm{H}_{2} \mathrm{O}$ solution $\left(45^{\cdot 2} \mathrm{~g} / \mathrm{l}\right)$ plus $7 \mathrm{ml} \mathrm{NaOH}$ solution $(50 \cdot 4 \mathrm{~g} / \mathrm{l}) ; \mathrm{pH}$ adjusted to 7.2 with additional $\mathrm{NaOH}$ ). The muscles were then dissected out, freed from any residual connective tissue and fat, and returned to the fixative solution. The muscles were dehydrated in ethanol, cleared in cedar-wood oil, embedded in Paraplast wax (Sherwood Medical Industries Ltd, Crawley, Sussex), and transverse $7 \mu \mathrm{m}$ sections cut on a Beck rotary microtome (Beck Instruments Ltd, Watford, Herts.). The sections were stained in Delafield's haematoxylin and eosin, and projected onto white paper using a projection microscope (E. Leitz (Instruments) Ltd, London WIN 8BB). The total number of muscle fibres was counted using an electronic pen counter, and the total number of nuclei visible in the transverse section was also counted.

The total number of nuclei in each muscle was calculated in the following way. If 
$n$ is the apparent number of nuclei counted in the muscle transverse section, then the real number $(N)$ of whole nuclei in the section $=\frac{\mathrm{T}}{\mathrm{T}+\mathrm{D}} \times n$ (Abercrombie, 1946) In this instance, thickness of the sections $(\mathrm{T})$ was about the same as the diameter of the nuclei (D) in the long axis. This was found by measuring them in a longitudinal section of pig muscle; the maximum length was found to be about $8 \mu \mathrm{m}$. It may be added here that Strobykina (1970) found that lengths of nuclei remained the same throughout the growth of Large White pigs. Therefore, it seemed reasonable to assume that the length of the nuclei would be the same in all the sections and approximately equal to their thickness. Therefore, $N=\frac{n}{2}$.

The approximate volume $(\mathrm{V})$ of the indicator muscle was calculated using the formula:

$$
\mathrm{V}=\left(\mathrm{A} \times \frac{l}{3}\right)+\left(\frac{\mathrm{A}}{3} \times \frac{2 l}{3}\right)
$$

where $A$ is the area of section taken in the 'belly' of the muscle, from which nuclei counts were made; $l$ is the length of the muscle in its wax block; $\mathrm{A} \times \frac{l}{3}$ is the volume of the cylindrical part of the muscle; $\frac{\mathrm{A}}{3} \times \frac{2 l}{3}$ is the volume of the tapering part of the muscle, corresponding to the volume of a cone.

It follows that the total number of nuclei in the muscle is then: $\frac{N}{\mathrm{AT}} \times \mathrm{V}$. The concentration of nuclei in the muscle was calculated by dividing the total number of nuclei by $\mathrm{V}$.

Determination of DNA. In some of the pigs the indicator muscle from the right fore-foot was removed almost immediately after the death of the animal, cleaned of connective tissue as far as possible and then weighed and stored at $-20^{\circ}$ until used for the determination of DNA.

DNA was extracted by the method of Zamenhof, Bursztyn, Rich \& Zamenhof (1964) and estimated as described by Burton (1956).

\section{RESULTS}

\section{Size and number of muscle fibres}

Table I gives the body-weights, the volumes of the muscles, and the number and diameter of the muscle fibres. The differences between the body-weights of the animals that had received the various treatments have already been described (see p. 422) and these differences in weights are reflected in the diameter of the muscle fibre. It was found, not surprisingly, that the correlation between muscle volume and body-weight $(r 0.995)$ was significantly higher $(P<0.05)$ than the correlation between fibre diameter and body-weight $(r 0.937)$. Mean distributions of fibre diameter for all these groups are shown in Fig. I; all are unimodal with nearly normal distributions.

For each of the six groups shown in Table I a separate one-way analysis of variance 
Table 1 . Body-weights, volumes of $m$. flexor digiti $V$ brevis muscles, and number and diameter of muscle fibres from well-nourished, energy-deficient and protein-deficient pigs

\begin{tabular}{|c|c|c|c|c|c|c|c|}
\hline Nutritional status* & Age & $\begin{array}{l}\text { Pig } \\
\text { no. }\end{array}$ & Sex & $\begin{array}{c}\text { Body-wt } \\
\text { (kg) }\end{array}$ & $\begin{array}{c}\text { Volume of } \\
\text { muscle } \\
\text { (mm†) }\end{array}$ & $\begin{array}{l}\text { Total } \\
\text { no. of } \\
\text { fibres }\end{array}$ & $\begin{array}{c}\text { Mean } \\
\text { diameter } \\
\text { of fibres } \\
(\mu \mathrm{m})\end{array}$ \\
\hline Well-nourished & IOd & $\begin{array}{l}F_{1} \\
F_{2} \\
G_{1} \\
G_{2} \\
G_{3}\end{array}$ & $\begin{array}{l}0 \\
0 \\
0 \\
+ \\
+ \\
0\end{array}$ & $\begin{array}{l}3 \cdot 75 \\
4.65 \\
3 \cdot 10 \\
3 \cdot 40 \\
2 \cdot 93\end{array}$ & $\begin{array}{l}\text { I I.7 } \\
I 7 \cdot 0 \\
10.5 \\
12.0 \\
I I \cdot 8\end{array}$ & $\begin{array}{l}5420 \\
5710 \\
5600 \\
5890 \\
6000\end{array}$ & $\begin{array}{l}13.4 \\
15.9 \\
13.4 \\
15.0 \\
16.4\end{array}$ \\
\hline Well-nourished & I year & $\begin{array}{l}\mathrm{A}_{I} \\
\mathrm{BI}_{\mathrm{I}} \\
\mathrm{C}_{\mathrm{I}} \\
\mathrm{D}_{\mathrm{I}} \\
\mathrm{E}_{\mathrm{I}}\end{array}$ & $\begin{array}{l}q \\
+ \\
q \\
q \\
q \\
q\end{array}$ & $\begin{array}{l}2 \times 5 \\
225 \\
206 \\
208 \\
167\end{array}$ & $\begin{array}{r}-- \\
-- \\
472 \\
482 \\
414\end{array}$ & $\begin{array}{l}454 I \\
4893 \\
6410 \\
5740 \\
5380\end{array}$ & $\begin{array}{l}58 \cdot 0 \\
70 \cdot 1 \\
59 \cdot 5 \\
58 \cdot 3 \\
62 \cdot 2\end{array}$ \\
\hline Energy-deficient & I year & $\begin{array}{l}\mathrm{A}_{2} \\
\mathrm{~A}_{3} \\
\mathrm{C}_{2} \\
\mathrm{C}_{3} \\
\mathrm{D}_{2} \\
\mathrm{D}_{3}\end{array}$ & $\begin{array}{l}0 \\
0 \\
0 \\
0 \\
0 \\
0 \\
0\end{array}$ & $\begin{array}{l}5 \cdot 05 \\
5 \cdot 75 \\
7 \cdot 35 \\
6 \cdot 30 \\
6 \cdot 55 \\
6 \cdot 15\end{array}$ & $\begin{array}{l}- \\
- \\
16.9 \\
20.2 \\
24.1 \\
15.7\end{array}$ & $\begin{array}{l}4571 \\
5267 \\
5864 \\
6480 \\
5344 \\
5680\end{array}$ & $\begin{array}{l}19.8 \\
22.3 \\
17.9 \\
19.2 \\
23.1 \\
19.4\end{array}$ \\
\hline Energy-deficient & 2 years & $\begin{array}{l}\mathrm{A}_{5} \\
\mathrm{~A}_{6} \\
\mathrm{~B}_{3} \\
\mathrm{~B}_{4} \\
\mathrm{C}_{5} \\
\mathrm{C} 6 \\
\mathrm{C} 8\end{array}$ & $\begin{array}{l}q \\
0 \\
0 \\
q \\
0 \\
0 \\
0 \\
+ \\
q\end{array}$ & $\begin{array}{r}11 \cdot 50 \\
9.65 \\
11 \cdot 35 \\
10 \cdot 10 \\
9.65 \\
10.15 \\
10.00\end{array}$ & $\begin{array}{l}52 \cdot 1 \\
23 \cdot 8 \\
24 \cdot 4 \\
29 \cdot 4 \\
42 \cdot 2 \\
39 \cdot 2 \\
36 \cdot 2\end{array}$ & $\begin{array}{l}5305 \\
4922 \\
4815 \\
5052 \\
6836 \\
6394 \\
6526\end{array}$ & $\begin{array}{l}24 \cdot 5 \\
24 \cdot 8 \\
22 \cdot 3 \\
25 \cdot 4 \\
25 \cdot 2 \\
29 \cdot 1 \\
26 \cdot 3\end{array}$ \\
\hline Protein-deficient & I year & $\begin{array}{l}\mathrm{A}_{4} \\
\mathrm{~B}_{2} \\
\mathrm{C}_{4} \\
\mathrm{D}_{4} \\
\mathrm{E}_{2}\end{array}$ & $\begin{array}{l}\text { } \\
\mathrm{CM} \\
\mathrm{CM} \\
\mathrm{CM} \\
\mathrm{CM}\end{array}$ & $\begin{array}{l}15.10 \\
16.05 \\
19.40 \\
14.40 \\
13.90\end{array}$ & $\begin{array}{l}- \\
74 \cdot 2 \\
28 \cdot 2 \\
21 \cdot 1\end{array}$ & $\begin{array}{l}4122 \\
4942 \\
5944 \\
5200 \\
4860\end{array}$ & $\begin{array}{l}3 r \cdot 0 \\
22 \cdot 7 \\
30 \cdot 2 \\
25 \cdot I \\
20 \cdot I\end{array}$ \\
\hline Protein-deficient & 2 years & $\begin{array}{l}\mathrm{A}_{7} \\
\mathrm{~B}_{5} \\
\mathrm{C}_{7} \\
\mathrm{D}_{5} \\
\mathrm{E}_{3}\end{array}$ & $\begin{array}{c}\text { CM } \\
q \\
q \\
q \\
q \\
+ \\
q\end{array}$ & $\begin{array}{l}27 \cdot 45 \\
16 \cdot 90 \\
29 \cdot 35 \\
29 \cdot 90 \\
22 \cdot 55\end{array}$ & $\begin{array}{l}43.0 \\
45^{\circ} 4 \\
91.5 \\
44^{\circ} 0 \\
43^{\circ} 0\end{array}$ & $\begin{array}{l}4355 \\
4808 \\
6862 \\
6885 \\
5271\end{array}$ & $\begin{array}{l}31 \cdot 9 \\
29 \cdot 3 \\
37 \cdot 6 \\
37 \cdot 1 \\
31 \cdot 7\end{array}$ \\
\hline
\end{tabular}

A, B, C, D, E, F, G, litters from which pigs came; CM, castrated male.

* For details, see p. 422 .

$\uparrow$ For details of calculation, see p. 423 .

was made for total number of muscle fibres. Since sex has been found to have no effect on fibre number (Staun, 1963; Rowe, r968; Stickland, r973), all animals in the group have been taken together. It was found that, except for the well-nourished, ro-d-old pigs, 'between-animals' variance was very much smaller than 'betweenlitters' variance. 'Between-animals' variance did not appear to vary in any systematic manner with treatment or age, whereas 'between-litters' variance appeared to increase with age of the animal.

For the next stage of the analysis the well-nourished, ro-d-old animals were omitted because the litters used in this group were different from other groups. For the remaining five groups or treatments a table was produced (Table 2) of the mean 
Vol. 34

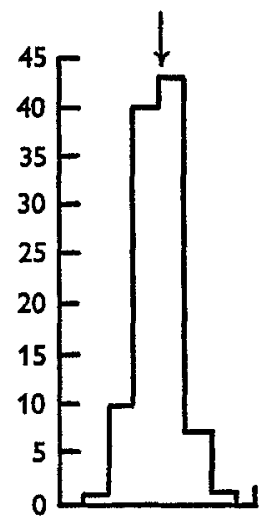

(a)

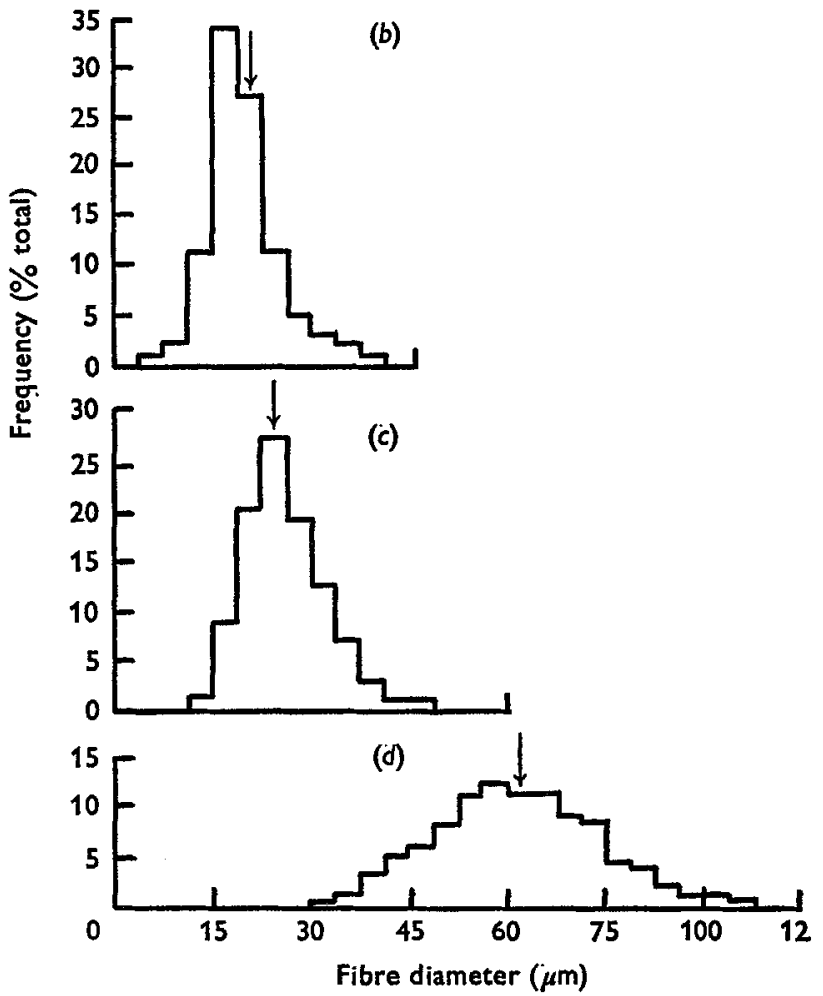

Fig. I. Distribution of fibre diameters of $\mathrm{m}$. flexor digiti $\mathrm{V}$ brevis muscles of pigs. (a) Wellnourished, IO-d-old; $(b)$ energy-deficient, I-year-old; $(c)$ protein-deficient, I-year-old; $(d)$ well-nourished, I-year-old. For details of treatments, see p. 422.

observed total fibre number for each treatment from each litter. Mean values could be used because 'between-animal' variation is small relative to 'between-litter' variation. The table was analysed by analysis of variance weighted inversely by the square of the animals' ages in order to correct for the relationship found between age and 'between-litter' variance. The analysis indicated that 'litter-to-litter' variability accounts for most of the variation in fibre number and is highly significant $\left(\begin{array}{l}F \\ 23.57\end{array}\right.$ $\left.f_{1} 4, f_{2} 12, P<0.001\right)$. Treatment differences were not significant $\left(F 2 \cdot 78, f_{1} 4, f_{2} 12\right)$. 
Table 2. Two-way analysis of variance for total fibre number for $m$. flexor digiti $V$ brevis muscles from well-nourished, energy-deficient and protein-deficient pigs

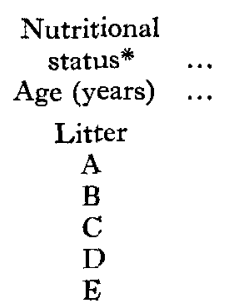

Weighting

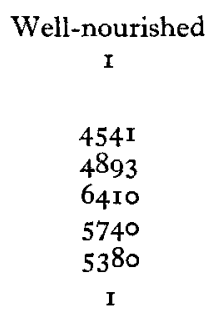

* For details, see p. 422 .
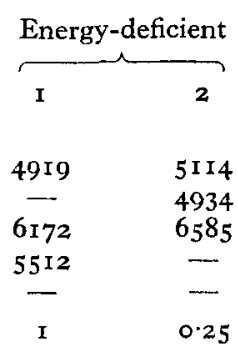

0.25
Protein-deficient

$\begin{array}{cc}\text { I } & 2 \\ 4122 & 4355 \\ 4942 & 4808 \\ 5944 & 6862 \\ 5200 & 6885 \\ 4860 & 5271 \\ \text { I } & 0.25\end{array}$

Table 3. Number of nuclei and amount of DNA in $m$. flexor digiti $V$ brevis muscles from well-nourished, energy-deficient and protein-deficient pigs

\begin{tabular}{|c|c|c|c|c|c|c|c|}
\hline \multirow[b]{2}{*}{$\begin{array}{c}\text { Nutritional } \\
\text { status* }\end{array}$} & \multirow[b]{2}{*}{ Age } & \multirow[b]{2}{*}{$\begin{array}{l}\text { Pig } \\
\text { no. }\end{array}$} & \multirow[b]{2}{*}{ Sex } & \multicolumn{2}{|c|}{ Nuclei } & \multicolumn{2}{|c|}{ DNA } \\
\hline & & & & $\begin{array}{c}\mathrm{No} / \mathrm{mm}^{3} \\
\left(\times 10^{3}\right)\end{array}$ & $\begin{array}{c}\text { Total no. } \\
\left(\times 10^{3}\right)\end{array}$ & $\begin{array}{l}\mathrm{mg} / \mathrm{g} \\
\text { muscle }\end{array}$ & $\begin{array}{c}\text { Total } \\
\text { (mg/ } \\
\text { muscle) }\end{array}$ \\
\hline Well-nourished & lo d & $\begin{array}{l}F_{1} \\
F_{2} \\
G_{1} \\
G_{2} \\
G_{3}\end{array}$ & $\begin{array}{l}0 \\
0 \\
0 \\
+ \\
q \\
0\end{array}$ & $\begin{array}{l}388 \\
283 \\
380 \\
395 \\
401\end{array}$ & $\begin{array}{l}4530 \\
4804 \\
3990 \\
4740 \\
4731\end{array}$ & $\begin{array}{l}3 \cdot 64 \\
3 \cdot 57 \\
3 \cdot 09 \\
3 \cdot 50 \\
3 \cdot 22\end{array}$ & $\begin{array}{l}0.17 \\
0.25 \\
0.13 \\
0.16 \\
0.17\end{array}$ \\
\hline Well-nourished & I year & $\begin{array}{l}C_{1} \\
D_{I} \\
E_{1}\end{array}$ & $\begin{array}{l}9 \\
9 \\
9\end{array}$ & $\begin{array}{l}78.6 \\
79.0 \\
85.4\end{array}$ & $\begin{array}{l}37114 \\
38 \text { 102 } \\
353 \times 6\end{array}$ & $\begin{array}{l}0.84 \\
0.81 \\
0.60\end{array}$ & $\begin{array}{l}I \cdot 40 \\
I \cdot 17 \\
0.78\end{array}$ \\
\hline Energy-deficient & I year & $\begin{array}{l}\mathrm{C}_{2} \\
\mathrm{C}_{3} \\
\mathrm{D}_{2} \\
\mathrm{D}_{3}\end{array}$ & $\begin{array}{l}\hat{0} \\
\hat{0} \\
\hat{0} \\
q\end{array}$ & $\begin{array}{l}211 \\
208 \\
210 \\
268\end{array}$ & $\begin{array}{l}3566 \\
4201 \\
5056 \\
4196\end{array}$ & $\begin{array}{l}\overline{2 \cdot 13} \\
\overline{I \cdot 61}\end{array}$ & $\begin{array}{l}\overline{0.25} \\
\overline{0.12}\end{array}$ \\
\hline Energy-deficient & 2 years & $\begin{array}{l}A_{5} \\
A_{6} \\
B_{3} \\
B_{4} \\
C_{5} \\
C 6 \\
C 8\end{array}$ & $\begin{array}{l}q \\
0 \\
q \\
0 \\
\delta \\
0 \\
0 \\
q\end{array}$ & $\begin{array}{r}128 \\
113 \\
138 \\
115 \\
126 \\
98 \\
114\end{array}$ & $\begin{array}{l}6675 \\
2689 \\
3361 \\
3377 \\
5322 \\
3843 \\
4123\end{array}$ & $\begin{array}{l}- \\
- \\
- \\
- \\
-\end{array}$ & $\begin{array}{l}- \\
- \\
- \\
- \\
-\end{array}$ \\
\hline Protein-deficient & 1 year & $\begin{array}{l}\mathrm{C}_{4} \\
\mathrm{D}_{4} \\
\mathrm{E}_{2}\end{array}$ & $\begin{array}{l}\mathrm{CM} \\
\mathrm{CM} \\
\mathrm{CM}\end{array}$ & $\begin{array}{l}\text { I } 8 \\
\text { I } 73 \\
2 \text { II }\end{array}$ & $\begin{array}{l}8759 \\
4874 \\
4462\end{array}$ & $\begin{array}{l}- \\
1.03 \\
1.43\end{array}$ & $\begin{array}{l}- \\
0.14 \\
0.34\end{array}$ \\
\hline Protein-deficient & 2 years & $\begin{array}{l}\mathrm{A}_{7} \\
\mathrm{~B}_{5} \\
\mathrm{C}_{7} \\
\mathrm{D}_{5} \\
\mathrm{E}_{3}\end{array}$ & $\begin{array}{c}\text { CM } \\
q \\
q \\
q \\
q \\
q\end{array}$ & $\begin{array}{l}105 \\
120 \\
107 \\
136 \\
105\end{array}$ & $\begin{array}{l}45 \times 6 \\
5442 \\
9789 \\
5979 \\
45 \times 6\end{array}$ & $\begin{array}{l}- \\
- \\
-\end{array}$ & $\begin{array}{l}- \\
- \\
-\end{array}$ \\
\hline
\end{tabular}

A, B, C, D, E, F, G, litters from which the pigs came; CM, castrated male.

* For details, see p. 422 .

\section{Number of nuclei and amount of $D N A$}

The number of nuclei and amount of DNA in the muscle are shown in Table 3. The number of nuclei $/ \mathrm{mm}^{3}$ and amount of DNA (mg/g muscle) was inversely related to body-weight (for number of nuclei per $\mathrm{mm}^{3}: r 0.424, P<0.05$ ). The values were 
highest in the Io-d-old pigs, followed by r-year-old, energy-deficient, I-year-old, protein-deficient and finally I-year-old, well-nourished pigs, in which concentrations of nuclei were relatively low. The total numbers of nuclei were directly related to body-weight $(r \circ .988, P<0.001)$ and to muscle weight, i.e., the I-year-old, control pigs had eight to ten times as many nuclei in their muscles as the animals in the other groups.

\section{DISCUSSION}

The results of this study suggest that severe undernutrition of pigs from Io $d$ of age does not reduce the total number of muscle fibres but it does affect their ability to increase in size. The number of fibres seems to have reached its adult value by $10 \mathrm{~d}$ after birth, and undernutrition even as severe as that imposed in this study caused no significant loss of fibres. The genetic make-up of the pig (the litter to which it belongs) on the other hand, is far more important in determining the number of muscle fibres than is the nutritional treatment to which the animal is subjected from Io $\mathrm{d}$ after birth. Whether severe undernutrition before this time of life would affect the number of muscle fibres still remains to be studied.

The present findings are consistent with the theories put forward by other workers, including Luff \& Goldspink ( 1967 ) working with mice and Staun ( 1963 ) working with pigs.

Fibre diameter appears to be related to the body-weight of the animal. Hence, the I-year-old, severely undernourished pig (mean body-weight $6.19 \mathrm{~kg}$ ) had smaller fibres than I-year-old pigs that had been given a diet low in protein (mean bodyweight $15.8 \mathrm{~kg}$ ), and both had smaller fibres than well-nourished, normal pigs of the same age (Table $\mathrm{I}$ and Fig. I). Periods of deprivation up to 2 years resulted in a slight increase in muscle fibre diameter and a small increase in body-weight. Differences in body-weight were relatively larger than differences in fibre diameter, but there were also differences in the lengths of the muscles. Volume and weight of the muscles were more closely related to body-weight than were the diameters of the fibres or the lengths of the muscles.

The extent of undernutrition used in the present study was much more severe than any used previously in studies on pigs and sheep, but the results for the number and diameter of muscle fibres are in agreement with other findings for farm animals less severely deprived. Montgomery, Dickerson \& McCance (1964) studied the effects of severe undernutrition (comparable to the levels used here) on the sartorius muscle in fowls. They reported that undernutrition prevented the normal increase in number of fibres which takes place in the sartorius muscle of the fowl after it has hatched. Smith (1963), on the other hand, found no increase in the number of muscle fibres in the sartorius muscle of fowls after hatching, and the reason for the failure of the number of fibres to increase, reported by Montgomery et al. (1964), is uncertain. Montgomery et al. (1964) found, however, that undernutrition of the adult bird did not significantly reduce the total number of muscle fibres.

The histological appearance (transverse sections) of the muscles of the energydeficient pigs showed that there was much more extracellular space in them than in muscles from well-nourished animals. This is in keeping with the results of Widdow- 
son, Dickerson \& McCance (1960), who showed that muscles from undernourished pigs contained much more extracellular water than muscles from well-nourished pigs of the same age, and more even than muscles from newborn pigs. The muscles from the energy-deficient pigs contained many small, irregularly shaped fibres as well as some larger, regularly shaped, polygonal ones. Fibres from well-nourished and protein-deficient animals were regularly shaped. From the histogram in Fig. I it can be seen that most of the fibres in the muscles of energy-deficient pigs were the same size as those of the Io-d-old animals; these were the irregularly shaped fibres. Some fibres were larger and these cause the mean value for muscles of energy-deficient animals to be higher than those from the ro-d-old animals. All the histograms are unimodal with peaks corresponding approximately to the mean value (Fig. I) for that particular group. The variation in size of fibres increased as the mean fibre size increased, except for the muscles of the protein- and energy-deficient pigs, which had different mean values but the same distribution width.

In this study the total number of nuclei in the indicator muscle was related to the body-weight and size of the muscle, and so was higher in the heavier pigs. This is in agreement with Montgomery (1962) and Cheek (1968), who found that the number of nuclei increased with muscle growth in man. Concentration of nuclei, however, was highest in pigs with a low body-weight. This is in accordance with the findings of Montgomery et al. (1964) for the number of nuclei in the sartorius muscle of fowls.

The results taken as a whole strongly suggest that severe undernutrition, although affecting the size of the fibres in a pig's muscle, does not interfere with their number. The latter seems to be determined by about the time of birth.

The authors thank Dr P. Lerman for assisting with the statistical analysis of the results.

\section{REFERENCES}

Abercrombie, M. (1946). Anat. Rec. 94, 239.

Burton, K. (1956). Biochem. F. 62, 3 I5.

Cheek, D. B. (r968). Human Growth. Philadelphia: Lea \& Febiger.

Goldspink, G. (1964). F. cell. comp. Physiol. 63, 209.

Johnson, E. R. (1971). The growth and development of muscle and fat in the bovine carcase. PhD Thesis, University of Queensland.

Joubert, D. M. (1956). F. agric. Sci., Camb. 47, 59.

Luff, A. R. \& Goldspink, G. (1967). Life Sci. 6, I821.

McCance, R. A. (1960). Br. $\mathscr{F}$. Nutr. 14, 59.

McCance, R. A. (1968). In Calorie Deficiencies and Protein Deficiencies, p. 3 r 9 [R. A. McCance and E. M. Widdowson, editors]. London: J. \& A. Churchill.

McMeekan, C. P. (r940). F. agric. Sci., Camb. 30, 276.

McMeekan, C. P. (r94r). F. agric. Sci., Camb. 3r, r.

Montgomery, R. D. (1962). Nature, Lond. r95, I94.

Montgomery, R. D., Dickerson, J. W. T. \& McCance, R. A. (1964). Br. F. Nutr. 18, 587.

Rowe, R. W. D. (1968). F. $\exp$. Zool. 169, 59.

Smith, J. H. (1963). Poult. Sci. 42, 283.

Staun, H. (1963). Acta Agric. scand. 13, 293.

Stickland, N. C. (1973). The growth and development of skeletal muscle in pigs. PhD Thesis, University of Hull.

Stickland, N. C. \& Goldspink, G. (1973). Anim. Prod. 16, I35.

Strobykina, R. V. (1970). Svinarstvo, Kyyiv. Ir, 65 .

Widdowson, E. M., Dickerson, J. W. T. \& McCance, R. A. (1960). Br. F. Nutr. 14, 457.

Zamenhof, S., Bursztyn, H., Rich, K. \& Zamenhof, P. I. (I964). F. Neurochem. Ir, 505. 